\title{
Long-term fire effects of the drained open fen on organic soils
}

\author{
Marcin Sulwiński, Monika Mętrak, Małgorzata Suska-Malawska \\ University of Warsaw, Poland \\ Department of Plant Ecology and Environmental Conservation \\ Faculty of Biology, Biological and Chemical Research Centre \\ *Corresponding author’s e-mail: marcin.sulwinski@biol.uw.edu.pl
}

Keywords: wetland fire, peat fire, fen, wildfire.

\begin{abstract}
Fire has considerable impact on vegetation and organic soils properties. As we observed that the differences between vegetation of burnt and unburnt areas on the rich fen are visible 11 years after the fire, we assumed that the post-fire changes are long lasting, yet limited exclusively to the burnt areas. In order to check this hypothesis we studied spatial differentiation of physical and chemical properties of soils, and productivity capacities of burnt and unburnt areas in the fen in Biebrza National Park. We took soil samples from the neighboring burnt and unburnt areas, from the depth of $0-30 \mathrm{~cm}$ and $30-50 \mathrm{~cm}$. We analyzed 21 parameters of the soils including: $\mathrm{pH}$, ash content, moisture, bulk density, exchangeable $\mathrm{K}, \mathrm{Na}, \mathrm{Ca}$, available $\mathrm{P}, \mathrm{N}_{-} \mathrm{NH}_{4}^{+}, \mathrm{N}^{-} \mathrm{NO}_{3}^{-}$, total $\mathrm{N}, \mathrm{C}, \mathrm{K}$, $\mathrm{Na}, \mathrm{Ca}, \mathrm{Mg}, \mathrm{Fe}, \mathrm{P}$; and calculated C:N, C:P ratios. Surface layer of the burnt soils differed significantly from the unburnt soils in respect of 17 out of 21 parameters. The most pronounced difference was observed for available phosphorous (on average 6 times higher for the burnt soils). The differences in the deeper layer were mostly insignificant. The burnt areas were also characterized by twofold higher plant productivity than recorded for the unburnt areas. The influence of fire on peaty soils was long lasting but mostly limited to the surface layer of the soils. In the case of particular soil features, the post-fire differences were modified by advanced muck formation (moorshing) processes in the unburnt areas. Since the fire led to long lasting increase of fertility, the recovery of fen vegetation is unlikely.
\end{abstract}

\section{Introduction}

Mesotrophic open fens are groundwater fed, peat-forming ecosystems characterized by limited nutrient availability and no or low cover of trees and shrubs. Instead, they are dominated by highly specialized, often endangered herbaceous species (Bartoszuk 2005). Soils established on fens are well saturated with water, therefore if undisturbed, these ecosystems are resistant to fires. However, dehydration of the fen, either as a result of climate changes, or human activities, significantly increases risk of fire (Turetsky et al. 2015). Surface fires result in the burning of above ground plant biomass. Such fires can be used as a management tool for the removal of shrubs, enhancement of biodiversity or for protection of rare plant species (Middleton et al. 2006, Kimura and Tsuyuzaki 2011). Surface fires have usually short-term, minor influence on the soil chemical features, especially in comparison to smoldering fires (Laubhan 1995, Smith et al. 2001), which can last up to a few months and result in burning out of the muck surface layer of peat deposit (Kania et al. 2006, Watts and Kobziar 2013). The temperatures recorded during a smoldering fire are lower than during a typical flame combustion and range from 300 to $600^{\circ} \mathrm{C}$. Yet, long lasting peat smoldering inside the deposit impacts soil properties significantly (Neary et al. 1999, Rein et al. 2008).
Apart from eradication of the current vegetation cover (Kania et al. 2006) smoldering fires cause also seedbank destruction, soil sterilization (Rein et al. 2008) and significant changes in physical and chemical properties of peat (Marcos et al. 2007, Kania et al. 2006), leading to peat hydrophobicity (DeBano 2000) and the reduction of water storage capacity (Dikici and Yilmaz 2006), nutrients runoff from the burnt areas and eutrophication of surface water (McEachern et al. 2000), alterations of nutrients availability (Neary et al. 1999, Smith et al. 2001) which may promote the growth of undesirable plant species (Smith et al. 2001, Mętrak et al. 2008, Flores et al. 2011). Furthermore, during smoldering peat fires considerable amounts of toxic PAHs are produced and vast amounts of carbon dioxide are released into the atmosphere, enhancing climate changes (Benscoter and Wieder 2003, Davies et al. 2013).

According to Rein et al. (2008) after an hour of peat heating at $300^{\circ} \mathrm{C}$, the sediment is totally sterile and irreversibly changed, as far as its physical and chemical properties are concerned. Break down of organic matter initiates at $220^{\circ} \mathrm{C}$, leading to carbon and nitrogen emissions and phosphorous transformation into inorganic forms. At $500^{\circ} \mathrm{C}$, the full mineralization of organic matter takes place, including carbon and nitrogen volatilization (Giovannini et al. 1990). After a fire, mineral left-overs (ashes) alter physical and chemical properties 
of burnt soils. The duration of these changes depends on i.e. the amount and chemical composition of ashes. Elements released from peat and plant biomass during the fire may be lost via volatilization (e.g. C, N, S) or with ashes transported with smoke by convection forces. After the fire, remaining ashes can be removed by wind, water runoff, leaching downward soil profile or by plant uptake. They may be also transformed into insoluble compounds or remain in exchangeable form (Neary et al. 1999, Certini 2005, Dikici and Yilmaz 2006, Qian et al. 2009a, Qian et al. 2009b).

To the typical post-fire changes of soils we may include: increase in $\mathrm{pH}$, decrease in total amounts of nitrogen and carbon, and higher availability of $\mathrm{P}, \mathrm{K}, \mathrm{Ca}$ and $\mathrm{Mg}$. The ranges of these alterations differ, depending on the type of soil and the fire intensity (Neary et al. 1999, Marcos et al. 2007, Certini 2005, Ketterings and Bigham 2000, Arocena and Opio 2003, Dikici and Yilmaz 2006). Though the effects of fire on mineral soils are well examined, there is not enough information on its influences on physical and chemical properties, especially long-term ones, of peaty soils (Dikici and Yilmaz 2006, Wang et al. 2015). Hence, we present a study carried out in the area of a burnt-out fen, 11 years after an extensive, smoldering wildfire. Interestingly, even 11 years after the fire, the differences between vegetation of the burnt and unburnt areas are still visible, and boundaries between these areas are unambiguous. Assuming that the differences in vegetation reflect differences in soil properties, we may state that the post-fire changes of the mesotrophic open fen are long lasting and limited exclusively to the burnt areas.

The aim of the presented research was to study physical and chemical properties of peaty soils after the smoldering fire and check organic soil ability to recover to the pre-fire conditions.

Therefore we hypothesized as follows:

1. the effects of a smoldering fire on fen peaty soils are long lasting and manifested by clear and persistent differences in vegetation cover between unburnt and burnt areas (herbaceous plants versus trees and shrubs);

2. the changes of soil chemistry, i.e. increased trophic parameters, are limited exclusively to the burnt areas, the lack of eutrophication on unburnt areas restricts the development of trees and shrubs there.

\section{Materials and methods}

\section{Research site}

The presented research was carried out in Biebrza National Park, in Biele Suchowolskie rich fen (3380 ha) in the middle basin of the Biebrza River (N53'36'22" E2302'53"). This fen is supplied mostly with calcium rich ground waters and in spring also with flood waters from the Biebrza River. In the 1960 s, the eastern and southern parts of the fen were drained and transformed into meadows. As a result, considerable fluctuations of ground water level (from above ground level in spring, to about $-45 \mathrm{~cm}$ in autumn) and advanced muck formation process were observed, which highly increased the risk of wildfires. In 2002, in Biele Suchowolskie fen a smoldering fire occurred, which covered the area of 1230 ha and caused on average a peat loss of $30 \mathrm{~cm}$ (Kania et al. 2006). Our research was performed in the patchily burnt area, where both burnt and unburnt sites were present. The burn depth was approximately $10 \mathrm{~cm}$. Over a few years after the fire, the burnt patches were dominated by dense willow shrubs of Salix cinerea, while the unburnt patches remained covered with low, herbaceous vegetation, yet the typical fen species almost completely declined (currently it is a degraded fen sensu Klimkowska et al. (2010)). As these differences in vegetation are persistent, the boundaries between the burnt and the unburnt patches are still clearly distinguishable.

\section{Sampling pattern}

In 2013 we took 50 soil samples form Biele Suchowolskie fen according to the following pattern: the samples were taken from the neighboring burnt and unburnt patches (Fig. 1), covered respectively with willow shrubs and meadow vegetation, from the depth of $0-30 \mathrm{~cm}$ and $30-50 \mathrm{~cm}$ with the use of an Instorf sampler. The distance between a pair of samples from the neighboring burnt and unburnt patches ranged from 3 to $5 \mathrm{~m}$, to keep local habitat diversity at the minimum level, yet to have a proper representation of physical and chemical properties of the burnt and unburnt soils in samples. Additionally, in 2011 we removed willow shrubs from three $15 \mathrm{~m}^{2}$ plots within the burnt areas enabling succession of herbaceous species and measurements of their productivity. Thus, we could simply compare productivity of herbaceous vegetation developed on the burnt and unburnt soils, avoiding potential problems of incomparability between herbs and shrubs productivity measurements (Sala and Austin 2000). In 2014 we took plant biomass samples from 6 sites with the area of $0.25 \mathrm{~m}^{2}$ each, located in the neighboring unburnt and burnt patches ( 3 pairs of sites) (Fig. 1).

\section{Chemical analyses}

We assessed the following physical and chemical properties in the collected soil samples: (1) wet and dry bulk density and soil moisture (on mass basis) with the use of $100 \mathrm{~cm}^{3}$ steel cylinders; (2) the percentage content of ash (after ignition at $550^{\circ} \mathrm{C}$ ); (3) content of plant available $\mathrm{N}^{-\mathrm{NH}_{4}^{+}}$and $\mathrm{N}^{-\mathrm{NO}_{3}}{ }_{3}^{-}$ in $0.03 \mathrm{M}$ acetic acid according to Ostrowska et al. (1991) and measured with $\mathrm{San}^{++}$Continuous Flow Analyzer; (4) the content of plant available $\mathrm{P}$ (phosphate ions) in calcium lactate according to Egner et al. (1960) and measured with $\mathrm{San}^{++}$ Continuous Flow Analyzer; (5) the content of exchangeable K, $\mathrm{Na}$ and $\mathrm{Ca}$ in $1 \mathrm{M}$ ammonium acetate according to Ostrowska et al. (1991) and measured with flame photometer; (6) the total content of $\mathrm{K}, \mathrm{Na}$ and $\mathrm{Ca}$ measured with flame photometer after wet mineralization with nitric acid and hydrofluoric acid; (7) the total content of $\mathrm{Mg}$ and Fe measured with AAS (contrAA 700) and (8) total P content measured with $\mathrm{San}^{++}$Continuous Flow Analyzer after wet mineralization with nitric acid and hydrofluoric acid; (9) the total content of $\mathrm{N}$ and $\mathrm{C}$ with the use of NA 2500 CHNS elemental analyzer. All results were calculated on the basis of soil dry mass.

\section{Data analyses}

As the obtained data could not be assumed to be normally distributed, the differences between the samples from burnt and unburnt patches were evaluated with a non-parametric pair-difference Wilcoxon test. Correlations between the chosen parameters of the soils were assessed with Spearman's rank correlation coefficient. For the analyses we used Statistica for Windows v. 10. 

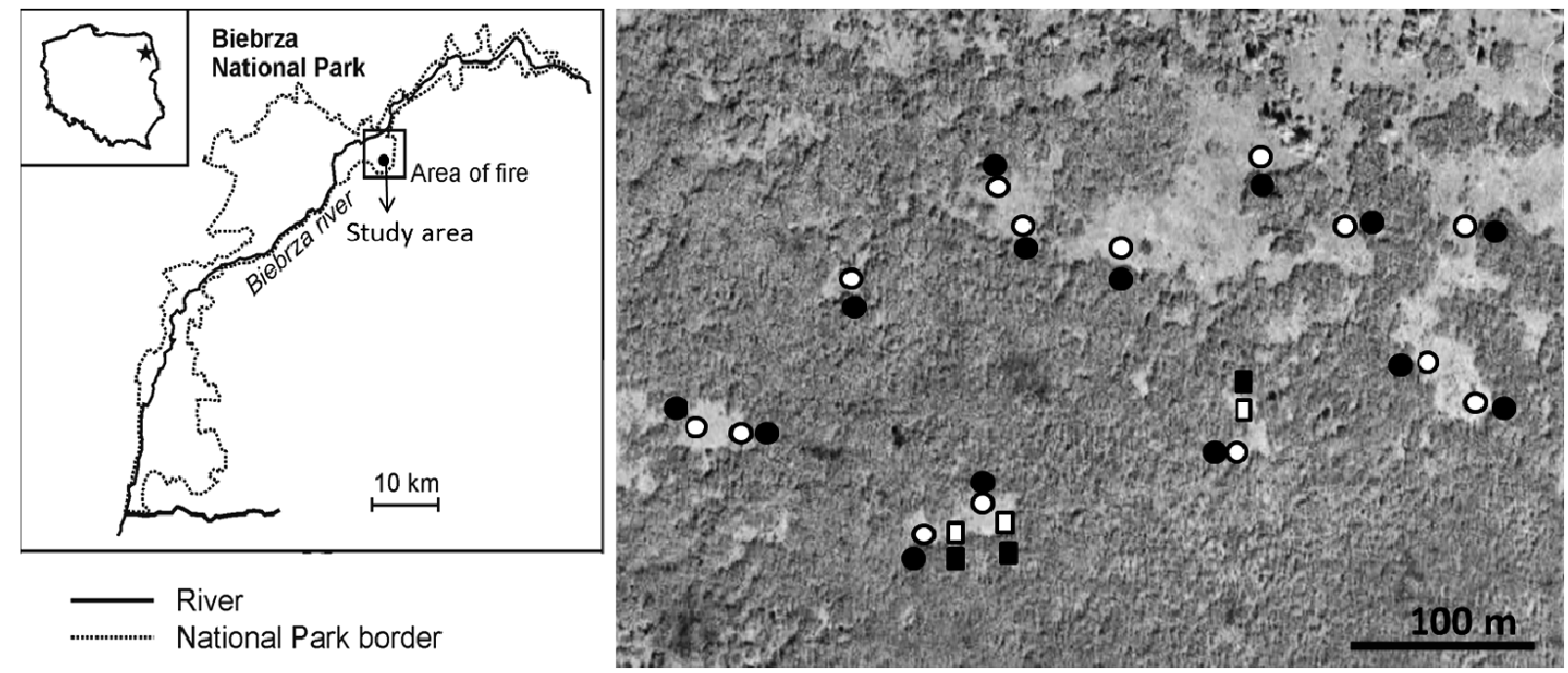

Fig. 1. Study area location and the sampling pattern used in the presented study.

Burnt areas covered by willows are dark grey, unburnt areas are light grey. White dots denote sampling places from the unburnt patches, black dots denote sampling places from the burnt patches. White squares denote sites for productivity measurements in unburnt patches, black squares denote sites for productivity measurements in burnt patches with shrubs removed.

\section{Results}

Differences in soil properties between the burnt and unburnt patches were considerable even 11 years after the fire. In the surface layer of the soil $(0-30 \mathrm{~cm})$ the differences between the burnt and unburnt patches were statistically significant for 17 of the 21 measured parameters. Yet, for the deeper layer $(30-50 \mathrm{~cm})$, we found statistically significant differences between the burnt and unburnt patches only for 3 out of 21 parameters (Tab. 1). The surface layer of the soil from the burnt patches was characterized by higher ash content $(p=0.001)$, higher wet bulk density $(p=0.013)$ and moisture $(p=0.01)$, higher $\mathrm{pH}(\mathrm{p}=0.001)$, higher content of exchangeable $\mathrm{Ca}$ $(\mathrm{p}=0.002)$ and available $\mathrm{P}(\mathrm{p}=0.001)$, higher total content of $\mathrm{Ca}(\mathrm{p}=0.002), \mathrm{Fe}(\mathrm{p}=0.005), \mathrm{Mg}(\mathrm{p}=0.004)$ and $\mathrm{P}(\mathrm{p}=0.013)$ than the surface layer of the soil from the unburnt patches. Simultaneously, it had lower content of exchangeable $\mathrm{K}$ $(p=0.004)$, available $\mathrm{N}-\mathrm{NH}_{4}^{+}(p=0.001)$ and $\mathrm{N}_{-} \mathrm{NO}_{3}{ }^{-}(p=0.001)$ and lower content of total $\mathrm{C}(\mathrm{p}=0.022)$ and $\mathrm{N}(\mathrm{p}=0.004)$. The most pronounced differences were recorded for the content of available $\mathrm{P}$ in the surface layer of the soil, with a median value for the burnt patches reaching $29.89 \mathrm{mg} \mathrm{P} / 100 \mathrm{~g}$ of the soil and only $5.03 \mathrm{mg} \mathrm{P} / 100 \mathrm{~g}$ of the soil for the unburnt patches $(\mathrm{p}=0.001)$ (Fig. 2). The $\mathrm{C}: \mathrm{N}$ ratio was higher in burnt patches, however $\mathrm{C}: \mathrm{P}$ ratio was clearly lower. These differences are the effect of differentiated $\mathrm{N}$ and $\mathrm{P}$ content, as $\mathrm{C}$ content has similar values in burnt and unburnt patches.

As far as the deeper layer of the soil $(30-50 \mathrm{~cm})$ is concerned, we recorded higher moisture $(p=0.033)$, higher content of available $\mathrm{P}(\mathrm{p}=0.004)$ and lower content of available $\mathrm{N}-\mathrm{NH}_{4}^{+}(\mathrm{p}=0.041)$ in the soils from the burnt patches in comparison to the soils from the unburnt patches.

As the differences in phosphorous content were the most pronounced, we analyzed further this element. It turned out that Spearman's rank correlation coefficient for the content of total $\mathrm{P}$ and total $\mathrm{Ca}$ in all the studied samples was statistically insignificant $(\mathrm{p}=0.8015)$, while for total $\mathrm{Mg}$ it was significant $(p=0.0129)$, yet rather low: 0.35 with $95 \%$ confidence interval from 0.08 to 0.57 . Contrarily, that Spearman's rank correlation coefficient for the content of total P and total Fe was both highly significant $(\mathrm{p}<0.0001)$ and high -0.78 with $95 \%$ confidence interval from 0.63 to 0.86 . Hence, we assumed that $\mathrm{P}$ in the both layers of the soil is bound mostly to Fe. Additionally, a mean molar ratio between total $\mathrm{P}$ and total $\mathrm{Fe}$ in the surface layer of all the soil samples studied was 11.4.

In 2014, after 3 years from willow removal, the burnt patches were dominated by common wet meadow species (i.e. Poa pratensis, Deschampsia caespitosa, Eupatorium cannabinum, Urtica dioica, Carex acutiformis, Poa palustris, Carex pseudocyperus), characterized by twofold higher productivity (mean productivity: $410 \mathrm{~g}$ dry mass $/ \mathrm{m}^{2}$ ) than recorded for the unburnt patches (mean productivity: $217 \mathrm{~g}$ dry mass $/ \mathrm{m}^{2}$ ). Over the period of our studies we did not record any typical fen species on the pretreated burnt patches.

\section{Discussion}

Peatlands fires intensity and depth of burn tend to be irregular and patchy, which is a result of local hydrologic conditions and microtopography of a particular wetland (Benscoter and Wieder 2003). Changes in fire intensity cause differences in temperature distribution in soil and also in the duration of fire. Both these factors are of paramount importance for the post-fire soils (Marcos et al. 2007). Due to the described unevenness of peatland fires, accessible information on their effects on soil properties is ambiguous. In their study on tropical soils, Ketterings and Bigham (2000) observed that the content of exchangeable cations and $\mathrm{C}$ and $\mathrm{N}$ had decreased to pre-burn levels in just a few weeks to a few months. Laubhan (1995) proved lack of differences in soil structure and macronutrients content between burnt and unburnt soils as soon as a few months after fire. On the other hand, according to Dikici and Yilmaz (2006) the effects of fire on particular soil properties (i.e. $\mathrm{pH}$, exchangeable $\mathrm{Ca}$, organic C) are persistent and distinguishable even 40 years after burning. 
Table 1. Differences in soil properties between the unburnt and the burnt patches. Values represent medians, statistics denote the results of non-parametric Wilcoxon test.

Asterisks denote significance levels: ${ }^{*} p<0.05,{ }^{* *} p<0.01,{ }^{* * *} p<0.001$, ns - not significant

\begin{tabular}{|c|c|c|c|c|c|c|}
\hline & \multirow{2}{*}{$\begin{array}{l}0-30 \mathrm{~cm} \\
\text { Unburnt } \\
\mathrm{n}=14\end{array}$} & \multirow[b]{2}{*}{$\begin{array}{l}\text { Burnt } \\
\mathrm{n}=14\end{array}$} & \multirow[b]{2}{*}{$\mathrm{p}$} & \multirow{2}{*}{$\begin{array}{l}30-50 \mathrm{~cm} \\
\text { Unburnt } \\
\mathrm{n}=11\end{array}$} & \multirow[b]{2}{*}{$\begin{array}{l}\text { Burnt } \\
n=11\end{array}$} & \multirow[b]{2}{*}{$p$} \\
\hline & & & & & & \\
\hline $\mathrm{pH}$ & 5.51 & 6.36 & ** & 5.60 & 5.59 & ns \\
\hline Ash content $\%$ & 20.21 & 25.19 & $* * *$ & 15.42 & 14.18 & ns \\
\hline Dry bulk density $\mathrm{g} / \mathrm{cm}^{-3}$ & 0.25 & 0.25 & ns & 0.18 & 0.15 & ns \\
\hline Wet bulk density $\mathrm{g} / \mathrm{cm}^{-3}$ & 0.93 & 0.99 & * & 0.99 & 1.01 & ns \\
\hline Moisture \% & 69.60 & 74.38 & ** & 81.25 & 83.57 & * \\
\hline $\mathrm{K}$ exchang. $\mathrm{mg} / 100 \mathrm{~g}$ & 9.51 & 6.47 & $* *$ & 3.02 & 3.06 & ns \\
\hline $\mathrm{Na}$ exchang. $\mathrm{mg} / 100 \mathrm{~g}$ & 2.89 & 3.25 & ns & 2.84 & 3.48 & ns \\
\hline Ca exchang. $\mathrm{mg} / 100 \mathrm{~g}$ & 1823 & 2249 & ** & 2385 & 2318 & ns \\
\hline $\mathrm{P}$ available $\mathrm{mg} / 100 \mathrm{~g}$ & 5.03 & 29.89 & $* *$ & 2.21 & 5.03 & ** \\
\hline $\mathrm{N}-\mathrm{NH}_{4}{ }_{4}^{+}$available $\mathrm{mg} / 100 \mathrm{~g}$ & 49.54 & 30.86 & $* *$ & 30.69 & 26.35 & * \\
\hline $\mathrm{N}-\mathrm{NO}_{3}{ }_{3}^{-}$available $\mathrm{mg} / 100 \mathrm{~g}$ & 0.60 & 0.22 & ** & 0.20 & 0.14 & ns \\
\hline $\mathrm{N}$ total $\%$ & 3.00 & 2.53 & $* *$ & 2.92 & 2.89 & ns \\
\hline C total $\%$ & 40.63 & 38.85 & * & 45.93 & 45.02 & ns \\
\hline $\mathrm{K}$ total $\%$ & 0.14 & 0.13 & $\mathrm{~ns}$ & 0.01 & 0.01 & $\mathrm{~ns}$ \\
\hline Na total \% & 0.04 & 0.04 & ns & 0.01 & 0.01 & ns \\
\hline Ca total \% & 2.69 & 3.84 & $* *$ & 3.47 & 3.34 & ns \\
\hline Fe total $\%$ & 3.32 & 4.21 & $* *$ & 1.71 & 1.59 & ns \\
\hline Mg total $\%$ & 0.14 & 0.20 & ** & 0.16 & 0.16 & ns \\
\hline $\mathrm{P}$ total $\%$ & 0.17 & 0.21 & * & 0.06 & 0.06 & ns \\
\hline C:N & 13.7 & 15.7 & * & 15.5 & 15.9 & ns \\
\hline$C: P$ & 242.4 & 184.9 & * & 763.5 & 845.7 & ns \\
\hline
\end{tabular}

In the case of Biele Suchowolskie fen, the effects of the fire were still visible after 11 years. Though we do not know the extent of the fire effects in 2002, we can assume that they were more pronounced by that time, and that the differences between the burnt and the unburnt patches are gradually decreasing. Previous studies of the fire effects on Biele Suchowolskie fen (Kania et al. 2006) described more prominent differences between the burnt and the unburnt patches than we recorded in 2013. As stated in Kania et al. (2006), 2 years after the fire, dry bulk density of burnt peat was almost twofold higher compared to the unburnt one. Moreover, the content of total $\mathrm{N}$ in the burnt peat did not exceed $1 \%$, while in the unburnt peat it was usually above $2.5 \%$. In like manner, both $\mathrm{pH}$ and ash content were more differentiated 2 years after the fire (Mętrak et al. 2006, Mętrak et al. 2008) than currently. According to our research, 11 years after the fire, differences in dry bulk density were insignificant and the mean difference in the content of total $\mathrm{N}$ was about $0.4 \%$. Similarly, differences in $\mathrm{pH}$ and ash content were lower compared to values reported in above-cited studies.

The results of our study suggest that the effects of fire were mostly limited to the surface layer of the soil $(0-30 \mathrm{~cm})$, leaving the deeper layer $(30-50 \mathrm{~cm})$ untransformed or only slightly changed. The deeper layer of the soil distinguished clearly from the surface layer for both the burnt and the unburnt soils. Comparative effects of fire, stronger in the surface layers of the soil, were recorded by i.e. Smith et al. (2001) and Ketterings and Bigham (2000). Limited impact of fire on the deeper layers of the soil might be a result of low heat transfer in moist soils.
Initially, both soil and soil water heat up to $95^{\circ} \mathrm{C}$ and keep this temperature until the water completely evaporates (Campbell et al. 1995). As long as this temperature is kept, neither decomposition of organic matter, or prominent changes in soil properties are recorded (Giovannini et al. 1990).

According to our research, the number of soil parameters significantly differentiating the burnt soils from the unburnt ones, is surprisingly high, considering the fact that the samples were taken 11 years after the fire and from neighboring localizations (distance of 3 to $5 \mathrm{~m}$ ). With the spring floodings characteristic for this type of fen, elements present in soil should be easily transported with water, leading to levelling of their content both in the depth of the soil profile and horizontally on the fen surface. However the differences in soil properties between the burnt and unburnt patches can be influenced not only by fire but also by the process of muck formation (peat organic matter decomposition caused by drainage (Okruszko 1991). In the burnt patches the surface muck layer was removed by the fire, leading to decrease in the distance between the ground water level and the new surface of the fen and thus slowing down decomposition processes. In the unburnt patches the muck layer is still present and the muck formation process is in advance, which is manifested by an increase in ash content and degradation of fen vegetation. Both processes (i.e. fire and muck formation) often lead to similar series of transformation of peaty soils, e.g. an increase in ash content and in bulk density. On the other hand, they may have opposite influence on soils, as showed in the Table 2. 
Table 2. Physical and chemical effects of fire and drainage on peaty soils. Range of transformations differs depending on intensity and duration of fire, degree of decomposition of peat and duration of dehydration of peat

\begin{tabular}{|c|c|c|c|c|c|}
\hline Parameter & $\begin{array}{l}\text { Effect } \\
\text { of fire }\end{array}$ & & $\begin{array}{l}\text { Effect of } \\
\text { drainage }\end{array}$ & & Citation \\
\hline $\mathrm{pH}$ & + & $\begin{array}{l}\text { Combustion of organic } \\
\text { acids, high content of } \\
\text { oxides and hydroxides } \\
\text { in ash }\end{array}$ & - & $\begin{array}{l}\text { Proton influx from oxidation of } \\
\text { organic and inorganic compounds, } \\
\text { increased leaching of base } \\
\text { elements, low inflow of base } \\
\text { elements with groundwater }\end{array}$ & $\begin{array}{l}\text { (Okruszko 1991, Neary et al. 1999, } \\
\text { Arocena and Opio 2003, Certini 2005, } \\
\text { Kania et al. 2006, Turetsky and Louis } \\
\text { 2006, Dikici and Yilmaz 2006, Qian et } \\
\text { al. 2009b) }\end{array}$ \\
\hline Ash content & + & $\begin{array}{l}\text { Combustion of organic } \\
\text { matter }\end{array}$ & + & $\begin{array}{l}\text { Increased mineralization of organic } \\
\text { matter }\end{array}$ & $\begin{array}{l}\text { (Okruszko 1991, Neary et al. 1999, } \\
\text { Smith et al. 2001, Kania et al. 2006) }\end{array}$ \\
\hline Dry bulk density & + & $\begin{array}{l}\text { Combustion of organic } \\
\text { matter, increased } \\
\text { content of ash }\end{array}$ & + & $\begin{array}{l}\text { Compaction of peaty soils, } \\
\text { increased content of ash }\end{array}$ & $\begin{array}{l}\text { (Okruszko 1991, Neary et al. 1999, } \\
\text { Smith et al. 2001, Kania et al. 2006) }\end{array}$ \\
\hline Moisture & + & $\begin{array}{l}\text { Decrease in the } \\
\text { distance between } \\
\text { ground water level and } \\
\text { a new surface of a fen }\end{array}$ & - & $\begin{array}{l}\text { Low ground water level, decreased } \\
\text { water holding capacity and capillary } \\
\text { conductivity in drained peaty soils. } \\
\text { Eventually, mitigation of water } \\
\text { shortage possible by subsidence } \\
\text { of peat deposit. }\end{array}$ & $\begin{array}{l}\text { (Okruszko 1991, Holden et al. 2004, } \\
\text { Dembek et al. 2005, Venterink et al. } \\
\text { 2009) }\end{array}$ \\
\hline K exchangeable & + & Influx with ash & - & $\begin{array}{l}\text { Increased leaching and prominent } \\
\text { decrease in } \mathrm{K} \text { concentration, } \\
\text { leading to degradation of } \\
\text { vegetation }\end{array}$ & $\begin{array}{l}\text { (Okruszko 1991, Mars et al. 1996, } \\
\text { Arocena and Opio 2003, Dikici and } \\
\text { Yilmaz 2006, Venterink et al. 2009) }\end{array}$ \\
\hline $\mathrm{N}-\mathrm{NH}_{4}{ }^{+}$available & $+/-$ & $\begin{array}{l}\text { Initial influx caused by } \\
\text { mineralization under } \\
\text { high temperatures, } \\
\text { followed by decrease } \\
\text { in concentration }\end{array}$ & + & $\begin{array}{l}\text { Increased mineralization } \\
\text { of organic } \mathrm{N}\end{array}$ & $\begin{array}{l}\text { (Okruszko 1991, Neary et al. 1999, } \\
\text { Holden et al. 2004) }\end{array}$ \\
\hline $\mathrm{N}-\mathrm{NO}_{3} \cdot$ available & $+/-$ & $\begin{array}{l}\text { Initial influx caused by } \\
\text { mineralization under } \\
\text { high temperatures, } \\
\text { followed by decrease } \\
\text { in concentration }\end{array}$ & + & $\begin{array}{l}\text { Increased mineralization } \\
\text { of organic } \mathrm{N}\end{array}$ & $\begin{array}{l}\text { (Okruszko 1991, Neary et al. 1999, } \\
\text { Holden et al. 2004, Tiemeyer et al. } \\
\text { 2007, Venterink et al. 2009) }\end{array}$ \\
\hline Ca exchangeable & + & Influx with ash & - & Increased leaching and runoff & $\begin{array}{l}\text { (Neary et al. 1999, Sundström et al. } \\
\text { 2000, Arocena and Opio 2003, Holden } \\
\text { et al. 2004, Dikici and Yilmaz 2006) }\end{array}$ \\
\hline$P$ available & + & Influx with ash & $+/-$ & $\begin{array}{l}\text { Initial influx caused by } \\
\text { mineralization of organic matter, } \\
\text { then reduction by binding to } \mathrm{Fe}, \mathrm{Al} \text {, } \\
\mathrm{Mg} \text { and } \mathrm{Ca}\end{array}$ & $\begin{array}{l}\text { (Mars et al. 1996, Neary et al. 1999, } \\
\text { Sundström et al. 2000, Smith et al. } \\
\text { 2001, Certini 2005, Venterink et al. } \\
\text { 2009, Wang et al. 2015) }\end{array}$ \\
\hline $\mathrm{N}$ total & - & $\begin{array}{l}\text { Combustion of organic } \\
\text { matter }\end{array}$ & $+1-$ & $\begin{array}{l}\text { Losses caused by mineralization } \\
\text { of organic matter, increase caused } \\
\text { by microbial } \mathrm{N} \text { immobilization }\end{array}$ & $\begin{array}{l}\text { (Okruszko 1991, Laine et al. 1995, } \\
\text { Neary et al. 1999, Sundström et al. } \\
\text { 2000, Smith et al. 2001, Holden et al. } \\
\text { 2004, Certini 2005, Venterink et al. } \\
\text { 2009, Qian et al. 2009b) }\end{array}$ \\
\hline C total & - & $\begin{array}{l}\text { Combustion of organic } \\
\text { matter }\end{array}$ & - & $\begin{array}{l}\text { Losses caused by microbial } \\
\text { decomposition }\end{array}$ & $\begin{array}{l}\text { (Okruszko 1991, Neary et al. 1999, } \\
\text { Smith et al. 2001, Certini 2005, Dikici } \\
\text { and Yilmaz 2006, Qian et al. 2009b) }\end{array}$ \\
\hline $\mathrm{K}$ total & + & Influx with ash & - & Increased leaching and runoff & $\begin{array}{l}\text { (Laiho and Laine 1995, Neary et al. } \\
\text { 1999, Sundström et al. 2000) }\end{array}$ \\
\hline Ca total & + & Influx with ash & - & Increased leaching and runoff & $\begin{array}{l}\text { (Laiho and Laine 1995, Laine et al. } \\
\text { 1995, Neary et al. 1999, Sundström et } \\
\text { al. 2000, Smith et al. 2001) }\end{array}$ \\
\hline Fe total & + & Influx with ash & $+/-$ & $\begin{array}{l}\text { Precipitation in aeration zone, } \\
\text { but sometimes increased leaching } \\
\text { and runoff }\end{array}$ & $\begin{array}{l}\text { (Laiho and Laine 1995, Neary et al. } \\
\text { 1999, Venterink et al. 2009) }\end{array}$ \\
\hline Mg total & + & Influx with ash & - & Increased leaching and runoff & $\begin{array}{l}\text { (Neary et al. 1999, Sundström et al. } \\
2000 \text { ) }\end{array}$ \\
\hline$P$ total & + & Influx with ash & + & Increased binding to $\mathrm{Fe}, \mathrm{Al}$ and $\mathrm{Ca}$ & $\begin{array}{l}\text { (Neary et al. 1999, Sundström et al. } \\
\text { 2000, Smith et al. 2001, Zak et al. } \\
\text { 2008, Qian et al. 2009b) }\end{array}$ \\
\hline
\end{tabular}


As a rule, fire increases soil content of elements which are not vaporized by high temperatures (Neary et al. 1999). Contrastingly, muck formation process enhances their release and washing out (Okruszko 1991, Laiho and Laine 1995). To some extent, these two opposite processes can help explain surprisingly long lasting differences between the burnt and unburnt patches in Biele Suchowolskie fen. In the case when both fire and moorhsing have the same effects on soil (e.g. increase in ash content, increase in content of Fe or P), we may assume that the existing differences were reinforced by the fire. In the case when fire and muck formation have opposite effects on soil, distinguishing between these two factors is rather hard. However, according to our research, we expect that muck formation might have stronger influence on the content of exchangeable and total $\mathrm{Ca}$ than fire. The $\mathrm{Ca}$ content was significantly decreased in the upper mucky, unburnt soils in comparison to the burnt soils and to the deeper layers of all the studied soils, which may indicate enhanced washing out of $\mathrm{Ca}$ ions (Fig. 2). Similarly, in the case of $\mathrm{NH}_{4}^{+}$ions, which are more abundant in the mucky, unburnt soils, which is probably a result of organic matter mineralization (Sapek 2008). In the burnt and deep soil layers, where mineralization is slower, the $\mathrm{NH}_{4}^{+}$contents are lower and uniform (Fig. 2).

The most pronounced difference between the burnt and the unburnt soils was in the content of available P. After 11 years from the fire, the available P content in the surface layer of the soil from the burnt patches was on average 6 times higher in comparison to the surface layer of the soil from the unburnt patches. Interestingly, Dikici Yilmaz (2006) observed no differences in P content in organic soils as early as 3 years after fire. Furthermore, we observed an increased content of $\mathrm{P}$ in the deeper layer of the burnt soils, which is probably a result of leaching of phosphate ions into the soil profile. Post-fire influxes of phosphates are dangerous for fen ecosystems as fens are fed by phosphate-poor water and plant biomass production is often P-limited (Wassen 1995). Increase in P availability can lead to the development of highly productive, expansive plant species, which displace less competitive fen species, adapted to low availability of nutrients (Verhoeven et al. 1996). Apart from fen eutrophication, also significant $\mathrm{P}$ loads into adjacent rivers and waterbodies may be expected, which also could cause shifts in vegetation (Grygoruk et al. 2015). According to Smith et al. (2001) a smoldering fire is followed by an increase in the content of phosphorous bound to $\mathrm{Mg}$ and $\mathrm{Ca}$ ions in the soil, while the content of phosphorous bound to Fe ions remains unchanged. In our case, correlation coefficient between total $\mathrm{P}$ and total Fe was highly significant and reached 0.78 , while in the case of $\mathrm{Ca}$ and $\mathrm{Mg}$ correlations coefficients were either insignificant or very low. Therefore, we assumed that phosphorus was bound mostly to iron ions. This situation is typical for drained fens, where the mucky, aerated surface layer occurs. In such layer phosphorous which was released via mineralization is accumulating into insoluble complexes i.e. with Fe ions (Zak et al. 2008). Accumulation of phosphorous bounded to $\mathrm{Fe}$ in the Biebrza River fens was observed by Mars et al. (1996). On the other hand, increased release of $\mathrm{P}$ is observed during restoration of drained wetlands, when proper hydrological conditions of a fen are restored. Increased ground water level leads to the establishment of reductive conditions and releases of $\mathrm{P}$ bounded to redox-sensitive Fe (III) compounds. This, in turn, results in high phosphate content in porewater (Zak and Gelbrecht 2007). Increase in P content in peaty soils can be also caused by extensive fluctuations of ground water level, resulting in alternate flooding and drying out of the soil surface layer (Olila et al. 1997). Probably, this mechanisms also influence $\mathrm{P}$ transformations in the soils from Biele Suchowolskie fen, hence hydroxides and hydrated oxides of $\mathrm{Fe}$ from ash could easily bind to mineralized $\mathrm{P}$, thanks to high binding affinity of $\mathrm{Fe}(\mathrm{OH})_{3}$ to $\mathrm{P}$ (Lijklema 1980). Therefore, we assume that after the fire, in peaty soils from Biele Suchowolskie fen accumulation of redox-sensitive P-Fe(III) compounds occurred. Post-fire lowering of the fen surface caused longer and deeper spring floodings, and prolonged reductive conditions, resulting in $\mathrm{P}$ release. Molar ratio of Fe:P in the surface layer of the soil is about 11.4, which is close to the value considered by Zak et al. (2010) as promoting $\mathrm{P}$ release after flooding. As stated in Zak et al. (2014), the effects of increased availability of phosphorous can be long lasting.

As far as the distinct differences in vegetation cover between the burnt and unburnt patches are concerned, they are a result of persistent differences in physical and chemical properties of the studied soils. According to the accessible literature (Okruszko 1991, Mars et al. 1996, Klimkowska et al. 2010), in the areas where muck formation process is advanced, degradation of fen vegetation occurs caused by $\mathrm{K}$ deficiency in soil. Though in our case degradation was clearly visible, no $\mathrm{K}$ shortages were observed in the studied soils. Moreover, in the unburnt soils we recorded a higher content of $\mathrm{K}$ than in the burnt ones. However according to Venterink et al. (2009), even in areas with considerable limitation of plant growth caused by $\mathrm{K}$ deficiency, the content of exchangeable forms of $\mathrm{K}$ can be similar or even higher than in undisturbed areas, where $\mathrm{K}$ is not a limiting factor. The fire in Biele Suchowolskie fen caused decrease in the distance between ground water level and a new fen surface, resulting in higher soil moisture and lower intensity of decomposition processes. Though such conditions may support restoration of fen vegetation (Dembek et al. 2005), we observed an increase in productivity of plant communities established in the burnt patches, reaching $400 \mathrm{~g} \mathrm{~d} . \mathrm{m} . / \mathrm{m}^{2}$. The establishment of highly productive species excludes restoration of proper fen vegetation, consisting of low growing species adapted to nutrients shortages, which are easily outcompeted by fast growing, highly productive plants (Schrautzer et al. 2013).

\section{Conclusions}

After 11 years from the fire, differences in physical and chemical properties between the burnt and unburnt peaty soils still persist in Biele Suchowolskie drained fen. These differences are more prominent in the surface layer of the studied soils. The most pronounced difference was recorded in the content of available $\mathrm{P}$, which is on average 6 times higher in the burnt than in the unburnt soils. We assume that this difference is long lasting, so recovery of low productive vegetation is unlikely. These results indicate that prescribed fires on drained fens should not be applied because it may cause long lasting peat eutrophication. We observed advanced muck formation process in the unburnt areas, which causes profound changes in the properties of peaty soils. Some of these alterations are opposite to the effects of fire. Hence, apart from the effects of 

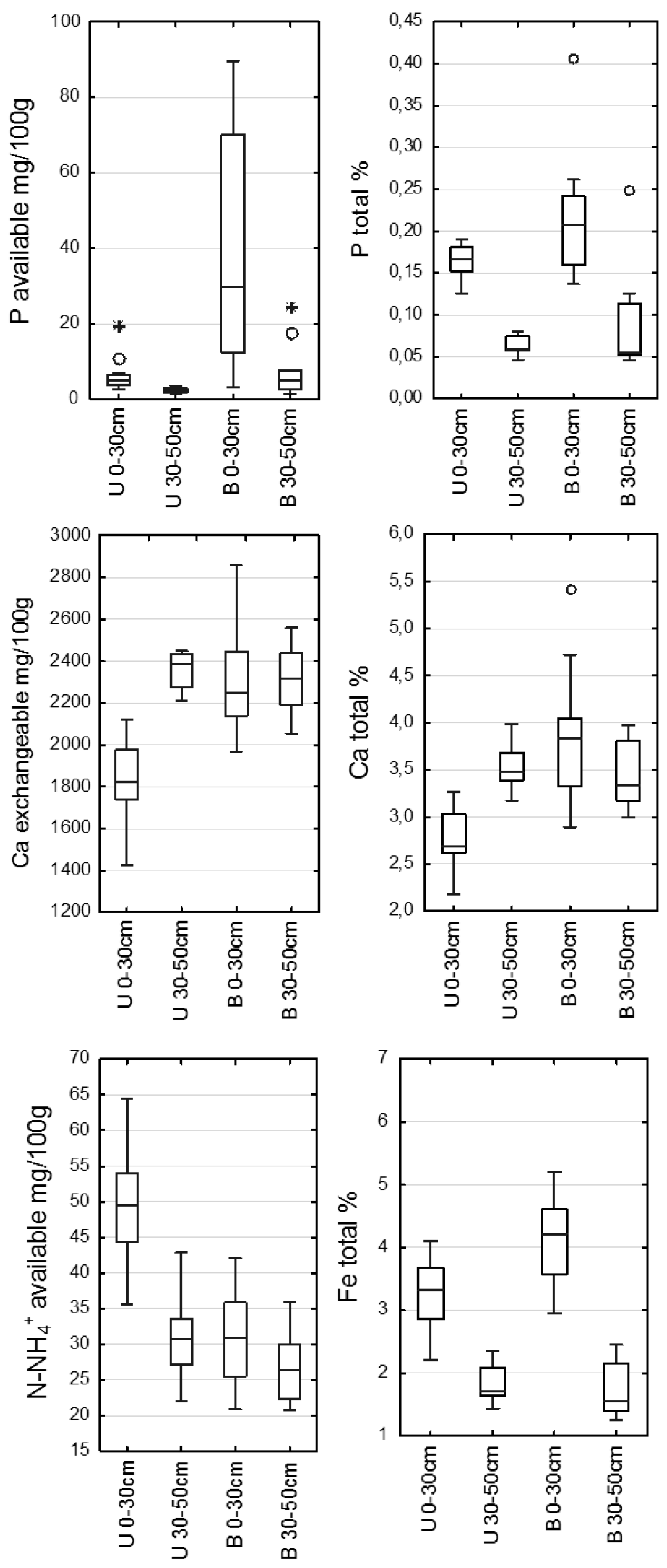

Fig. 2. Differences in soil properties between the unburnt and the burnt patches.

Abbreviations: $\cup$ 0 $-30 \mathrm{~cm}$ - unburnt soil from $0-30 \mathrm{~cm}$ layer, $U$ 30-50 cm unburnt soil from $30-50 \mathrm{~cm}$ layer, B 0-30 cm - burnt soil from $0-30 \mathrm{~cm}$ layer, B $30-50 \mathrm{~cm}-$ burnt soil from $30-50 \mathrm{~cm}$ layer. 
fire, persistence of recorded differences in soil properties and transformations of vegetation cover can be modified by muck formation process.

\section{Acknowledgements}

We thank the administration of the Biebrza National Park for enabling us performance of field studies. We are grateful to Monika Chmielewska, M.Sc. and. Beata Wójcik, M.Sc, for help in laboratory work. The study was carried out at the Biological and Chemical Research Centre, University of Warsaw, established within the project co-financed by European Union from the European Regional Development Fund under the Operational Program Innovative Economy, 2007-2013.

Funding: This work was supported by the Ministry of Higher Education and Science (Grant No 501/86-107441).

\section{References}

Arocena, J.M. \& Opio, C. (2003). Prescribed fire-induced changes in properties of sub-boreal forest soils, Geoderma, 113, 1, pp. 1-16.

Bartoszuk, H. (2005). Plant communities of Biebrza National Park, in: Przyroda Biebrzańskiego Parku Narodowego, Dyrcz, A. \& Werpachowski, C. (Eds). Monografia, Osowiec-Twierdza: BPN, pp. 133-148. (in Polish)

Benscoter, B.W. \& Wieder, R.K. (2003). Variability in organic matter lost by combustion in a boreal bog during the 2001 Chisholm fire, Canadian Journal of Forest Research, 33, 12, pp. 2509-2513.

Campbell, G.S., Jungbauer Jr, J.D., Bristow, K.L. \& Hungerford, R.D. (1995). Soil temperature and water content beneath a surface fire, Soil Science, 159, 6, pp. 363-374.

Certini, G. (2005). Effects of fire on properties of forest soils: A review, Oecologia, 143, 1, pp. 1-10.

Davies, G.M., Gray, A., Rein, G. \& Legg, C.J. (2013). Peat consumption and carbon loss due to smouldering wildfire in a temperate peatland, Forest Ecology and Management, 308, pp. $169-177$

DeBano, L.F. (2000). The role of fire and soil heating on water repellency in wildland environments: A review, Journal of Hydrology, 231-232, pp. 195-206.

Dembek, W., Oświt, J. \& Rycharski, M. (2005). Peatlands and peat in the Biebrza Urstromtal, in: Przyroda Biebrzańskiego Parku Narodowego, Dyrcz, A. \& Werpachowski, C. (Eds.). Monografia. Osowiec-Twierdza: BPN, pp. 33-58. (in Polish)

Dikici, H. \& Yilmaz, C.H. (2006). Peat fire effects on some properties of an artificially drained peatland, Journal of Environmental Quality, 35, 3, pp. 866-870.

Egner, H., Riehm, H. \& Domingo, W.R. (1960). Studies on chemical soil analysis as the basis for the assessment of nutrient status of soil. II: Chemical extraction methods for phosphorus and potassium determination, Kungliga Lantbrukshügskolans Annaler, 26, pp. 199-215. (in German)

Flores, C., Bounds, D.L. \& Ruby, D.E. (2011). Does prescribed fire benefit wetland vegetation?, Wetlands, 31, 1, pp. 35-44.

Giovannini, C., Lucchesi, S. \& Giachetti, M. (1990). Effects of heating on some chemical parameters related to soil fertility and plant growth, Soil Science, 149, 6, pp. 344-350.

Grygoruk, M., Bańkowska, A., Jabłońska, E., Janauer, G.A., Kubrak, J., Mirosław-Świątek, D. \& Kotowski, W. (2015). Assessing habitat exposure to eutrophication in restored wetlands: Model-supported ex-ante approach to rewetting drained mires, Journal of Environmental Management, 152, 5, pp. 230-240.

Holden, J., Chapman, P.J. \& Labadz, J.C. 2004. Artificial drainage of peatlands: hydrological and hydrochemical process and wetland restoration, Progress in Physical Geography, 28, 1, pp. 95-123.
Kania, J., Malawska, M., Gutry, P., Kamiński, J. \& Wiłkomirski, B. (2006). Environmental changes of fen caused by fire, Woda - Środowisko-Obszary Wiejskie, 2, 18, pp. 155-173. (in Polish)

Ketterings, Q.M. \& Bigham, J.M. (2000). Soil color as an indicator of slash-and-burn fire severity and soil fertility in Sumatra, Indonesia, Soil Science Society of America Journal, 64, 5, pp. 1826-1833.

Kimura, H. \& Tsuyuzaki, S. (2011). Fire severity affects vegetation and seed bank in a wetland, Applied Vegetation Science, 14, 3, pp. 350-357.

Klimkowska, A., Bekker, R.M., van Diggelen, R. \& Kotowski, W. (2010). Species trait shifts in vegetation and soil seed bank during fen degradation, Plant Ecology, 206, 1, pp. 59-82.

Laiho, R. \& Laine, J. (1995). Changes in mineral element concentrations in peat soils drained for forestry in Finland, Scandinavian Journal of Forest Research, 10, 1-4, pp. 218-224.

Laine, J., Vasander, H. \& Laiho, R. (1995). Long-term effects of water level drawdown on the vegetation of drained pine mires in southern Finland, Journal of Applied Ecology, 32, pp. 785-802.

Laubhan, M.K. (1995). Effects of prescribed fire on moist-soil vegetation and soil macronutrients, Wetlands, 15, 2, pp. 159-166.

Lijklema, L. (1980). Interaction of orthophosphate with iron(III) and aluminum hydroxides, Environmental Science and Technology, 14, 5, pp. 537-541.

Marcos, E., Tárrega, R. \& Luis, E. (2007). Changes in a humic cambisol heated $\left(100-500^{\circ} \mathrm{C}\right)$ under laboratory conditions: The significance of heating time, Geoderma, 138, 3-4, pp. 237-243.

Mars, H. De, Wassen, M. \& Peeters, W. (1996). The effect of drainage and management on peat chemistry and nutrient deficiency in the former Jegrznia-floodplain (NE-Poland), Vegetatio, 126, pp. 59-72.

McEachern, P., Prepas, E.E., Gibson, J.J. \& Dinsmore, W.P. (2000). Forest fire induced impacts on phosphorus, nitrogen, and chlorophyll a concentrations in boreal subarctic lakes of northern Alberta, Canadian Journal of Fisheries and Aquatic Sciences, 57, S2, pp. 73-81.

Mętrak, M., Malawska, M., Kamiński, J., Błocka, A. \& Wiłkomirski, B. (2008). Plant secondary succession patterns after 2002 wildfire in the Biebrza National Park, Phytopedon, 7, 2008/1, pp. 109-114.

Mętrak, M., Malawska, M., Kamiński, J. \& Wiłkomirski, B. (2006). Geochemical changes of peat soils and plant succession on the deeply burnt mires, Polish Journal of Environmental Studies, 15, 5D, pp. 57-66.

Middleton, B.A., Holsten, B. \& van Diggelen, R. (2006). Biodiversity management of fens and fen meadows by grazing, cutting and burning, Applied Vegetation Science, 9, pp. 307-316.

Neary, D.G., Klopatek, C.C., DeBano, L.F. \& Folliott, P.F. (1999). Fire effects on belowground sustainability: A review and synthesis, Forest Ecology and Management, 122, 1-2, pp. 51-71.

Okruszko, H. (1991). Wetlands transformation after draining, Zeszyty Problemowe Postępów Nauk Rolniczych, 372, pp. 251-267. (in Polish)

Olila, O.G., Olila, O.G., Reddy, K.R., Reddy, K.R., Stites, D.L. \& Stites, D.L. (1997). Influence of draining on soil phosphorus forms and distribution in a constructed wetland, Ecological Engineering, 9, pp. 157-169.

Ostrowska, A., Gawliński, S. \& Szczubiałka, Z. (1991). Metody analizy $i$ oceny właściwości gleb $i$ roślin, Warszawa: Instytut Ochrony Środowiska.

Qian, Y., Miao, S.L., Gu, B. \& Li, Y.C. (2009a). Effects of burn temperature on ash nutrient forms and availability from cattail (Typha domingensis) and sawgrass (Cladium jamaicense) in the Florida Everglades, Journal of Environmental Quality, 38, 2, pp. 451-464.

Qian, Y., Miao, S.L., Gu, B. \& Li, Y.C. (2009b). Estimation of postfire nutrient loss in the Florida everglades, Journal of Environmental Quality, 38, 5, pp. 1812-1820. 
Rein, G., Cleaver, N., Ashton, C., Pironi, P. \& Torero, J.L. (2008). The severity of smouldering peat fires and damage to the forest soil, Catena, 74, 3, pp. 304-309.

Sala, O.E. \& Austin, A.T. (2000). Methods of estimating aboveground net primary productivity, Methods in Ecosystem Science, pp. $31-43$.

Sapek, A. (2008). Phosphate and ammonium concentrations in groundwater from peat soils in relation to the water table, Polish Journal of Soil Science, 41, 2, pp. 139-148.

Schrautzer, J., Sival, F., Breuer, M., Runhaar, H. \& Fichtner, A. (2013). Characterizing and evaluating successional pathways of fen degradation and restoration, Ecological Engineering, 25, pp. 108-120.

Smith, S., Newman, S., Garrett, P. \& Leeds, J. (2001). Differential effects of surface and peat fire on soil constituents in a degraded wetland of the northern Florida Everglades, Journal of Environmental Quality, 30, 6, pp. 1998-2005.

Sundström, E., Magnusson, T. \& Hånell, B. (2000). Nutrient conditions in drained peatlands along a north-south climatic gradient in Sweden, Forest Ecology and Management, 126, 2, pp. 149-161.

Tiemeyer, B., Frings, J., Kahle, P., Köhne, S. \& Lennartz, B. (2007). A comprehensive study of nutrient losses, soil properties and groundwater concentrations in a degraded peatland used as an intensive meadow - implications for re-wetting, Journal of Hydrology, 345, 1-2, pp. 80-101.

Turetsky, M.R. \& Louis, V.L.S. (2006). Disturbance in boreal peatlands, in: Boreal Peatland Ecosystems, Wieder, R. \& Vitt, D. (Eds.). Berlin Heidelberg: Springer, pp. 359-379.

Turetsky, M.R., Benscoter, B., Page, S., Rein, G., van der Werf, G.R. $\&$ Watts, A. (2015). Global vulnerability of peatlands to fire and carbon loss, Nature Geoscience, 8, 1, pp. 11-14.
Venterink, H.O., Kardel, I., Kotowski, W., Peeters, W. \& Wassen, M.J. (2009). Long-term effects of drainage and hay-removal on nutrient dynamics and limitation in the Biebrza mires, Poland, Biogeochemistry, 93, 3, pp. 235-252.

Verhoeven, J.T.A., Koerselman, W. \& Meuleman, A.F.M. (1996). Nitrogen- or phosphorus-limited growth in herbaceous, wet vegetation: Relations with atmospheric inputs and management regimes, Trends in Ecology \& Evolution, 11, 12, pp. 494- 497.

Wang, G., Yu, X., Bao, K., Xing, W., Gao, C., Lin, Q. \& Lu, X. (2015). Effect of fire on phosphorus forms in Sphagnum moss and peat soils of ombrotrophic bogs, Chemosphere, 119, pp. 1329-1334.

Wassen, M.J. (1995). Hydrology, water chemistry and nutrient accumulation in the Biebrza fens and floodplains (Poland), Wetlands Ecology and Management, 3, 2, pp. 125-137.

Watts, A.C. \& Kobziar, L.N. (2013). Smoldering combustion and ground fires, Fire Ecology, 9, 1, pp. 124-132.

Zak, D. \& Gelbrecht, J. (2007). The mobilisation of phosphorus, organic carbon and ammonium in the initial stage of fen rewetting (a case study from NE Germany), Biogeochemistry, 85,2 , pp. 141-151.

Zak, D., Gelbrecht, J., Wagner, C. \& Steinberg, C.E.W. (2008). Evaluation of phosphorus mobilization potential in rewetted fens by an improved sequential chemical extraction procedure, European Journal of Soil Science, 59, 6, pp. 1191-1201.

Zak, D., Gelbrecht, J., Zerbe, S., Shatwell, T., Barth, M., Cabezas, A. \& Steffenhagen, P. (2014). How helophytes influence the phosphorus cycle in degraded inundated peat soils - Implications for fen restoration, Ecological Engineering, 66, pp. 82-90.

Zak, D., Wagner, C., Payer, B., Augustin, J. \& Gelbrecht, J. (2010). Phosphorus mobilization in rewetted fens: The effect of altered peat properties and implications for their restoration, Ecological Applications, 20, 5, pp. 1336-1349.

\title{
Długotrwały wpływ pożaru osuszonego torfowiska niskiego na właściwości gleb organicznych
}

\begin{abstract}
Streszczenie: Pożary wpływają istotnie na roślinność oraz właściwości gleb organicznych. Zaobserwowano, że nawet po 11 latach od wystąpienia podpowierzchniowego pożaru torfowiska niskiego wciąż istnieją wyraźne różnice pokrywy roślinnej obszarów wypalonych i niewypalonych. Na tej podstawie założono, że wpływ pożaru na ekosystem torfowiskowy jest długotrwały, jednak nie jest widoczny na sąsiednich obszarach niewypalonych. W celu weryfikacji tej hipotezy zbadano właściwości fizyczne i chemiczne gleby, a także produktywność biomasy roślinnej na torfowisku niskim zlokalizowanym w Biebrzańskim Parku Narodowym. Z sąsiadujących obszarów wypalonych oraz niewypalonych, z głębokości $0-30 \mathrm{~cm}$ oraz $30-50 \mathrm{~cm}$ pobrano próby gleby torfowej. Przeanalizowano 21 cech gleby: $\mathrm{pH}$, popielność, wilgotność, gęstość, wymiennie związane $\mathrm{K}, \mathrm{Na}, \mathrm{Ca}$, dostępne dla roślin $\mathrm{P}, \mathrm{N}_{-} \mathrm{NH}_{4}^{+}, \mathrm{N}_{-} \mathrm{NO}_{3}^{-}$, całkowite $\mathrm{N}, \mathrm{C}, \mathrm{K}, \mathrm{Na}, \mathrm{Ca}, \mathrm{Mg}, \mathrm{Fe}, \mathrm{P}$; oraz obliczono stosunki C:N, C:P, Fe:P. W 17 na 21 przebadanych cech stwierdzono istotne różnice w chemizmie wierzchniej warstwy gleby pobranej z miejsc wypalonych i niewypalonych. Najbardziej wyraźną różnicą było zwiększenie (średnio sześciokrotnie) zawartości dostępnego $\mathrm{P}$ w glebach z obszarów wypalonych. W większości badanych cech warstwy głębszej nie stwierdzono istotnych różnic. Obszary wypalone charakteryzowały się dwukrotnie wyższą produktywnością biomasy roślinnej. Stwierdzono, że wpływ pożaru na glebę torfową jest długotrwały i ograniczony głównie do jej wierzchniej warstwy. Część zaobserwowanych różnic może jednak wynikać z postępującego procesu murszenia torfu, zachodzącego na obszarach niewypalonych. $Z$ powodu zwiększenia dostępności pierwiastków biogennych scenariusz powrotu typowych zbiorowisk torfowisk niskich na obszary wypalone nie wydaje się prawdopodobny.
\end{abstract}

